02

\title{
Исследование структуры бивня мамонта методом ИК спектроскопии
}

\author{
(C) В.В. Павлова ${ }^{1}$, Е.С. Петухова ${ }^{1}$, Т.А. Исакова ${ }^{1, \uparrow}$, Е.С. Колесова ${ }^{1}$, А.А. Чириков ${ }^{1}$, Ф.Ф. Протопопов ${ }^{2}$ \\ ${ }^{1}$ Федеральный исследовательский центр „Якутский научный центр СО РАН“, \\ 677000 Якутск, Россия \\ ${ }^{2}$ Северо-восточный федеральный университет им. М.К. Аммосова, \\ 677010 Якутск, Россия \\ ฯ e-mail: tatyana_issakova@mail.ru
}

Поступила в редакцию 31.08.2021 г.

В окончательной редакции 18.11.2021 r.

Принята к публикации 22.11.2021 г.

Исследована структура бивня мамонта методом инфракрасной (ИК) спектроскопии, в том числе после термообработки. Выявлен весь комплекс функциональных групп компонентов бивня - гидроксиапатита, коллагена и воды. Установлено, что коллаген на ИК спектре представлен в основном характеристическими полосами поглощения амидных и алифатических группировок. После термообработки при $600^{\circ} \mathrm{C}$ органическая часть полностью удаляется из образца. Установлено, что гидроксиапатит в костных тканях бивня представлен в карбонатзамещенном виде, однако термообработка при $900^{\circ} \mathrm{C}$ приводит к удалению карбонатаниона и воды из пробы, что сопровождается переходом гидроксиапатита из нестехиометрического состояния в стехиометрическое.

Ключевые слова: бивень мамонта, инфракрасная спектроскопия, термообработка, коллаген, гидроксиапатит.

DOI: $10.21883 /$ OS.2022.03.52164.2643-21

\section{Введение}

Ископаемые костные остатки древних людей и животных являются объектами междисциплинарных исследований и служат источниками информации в палеонтологии, археологии, геологии, экологии и в других областях знаний, связанных с науками о прошлом. Для получения наиболее полной информации о данных уникальных объектах на современном этапе развития науки используется широкий комплекс методов и методик. Использование достаточно специализированных методов (радио-, масс- и ИК спектроскопии, рентгенофлюоресцентного анализа и микроанализа, атомной силовой и сканирующей микроскопии, газовой хроматографии и т.д. [1-20]) позволяет получить информацию о структурных особенностях ископаемых костных остатков и дает новые возможности для понимания особенностей жизнедеятельности людей и животных прошлого, а анализ изменений, произошедших с костными остатками в процессе залегания, позволяет в некоторой степени реконструировать ландшафты, климатические условия, гидрологию, геоморфологию всего района исследования, определить этапы формирования захоронений, время образования отложений и т.д. Метод ИК спектроскопии позволяет надежно и качественно определить наличие различных функциональных групп в объекте, причем оценка может производиться не только качественно, но и количественно. В палеонтологии данный метод нашел применение для анализа процессов, связанных с фазовыми и химическими превращениями костных тканей при фоссилизации, в понимании физико-химической сущности этого процесса. При этом дополнительный объем информации о динамике процессов фоссилизации ископаемой кости, которые протекают при совокупном воздействии ряда факторов (температура, влажность, УФ радиация, кислотность почвы и др.) можно получить, сравнивая ИК спектры, полученные с поверхности образца и из его объема [19].

Костные ткани как типичные биоминеральные агрегаты представляют из себя сложные образования и содержат минеральные и органические составляющие, имеют неповторимый рельеф, форму, текстуру поверхности, микро- и нанопоры, специфический микроэлементный и изотопный состав. Валовый химический состав ископаемых костей колеблется в широких пределах, включая не только компоненты биоапатита, но и множество других компонентов, появление которых, очевидно, обусловлено фоссилизацией [20]. Морфология кристаллов биоапатита, их взаимное расположение и связь с органическим компонентом позволяют рассматривать костную ткань как уникальный природный материал, в котором жесткий армирующий минерал находится в эластичной матрице [21].

Объектом исследования данной работы будет являться бивень мамонта, изучение которого представляет интерес не только для фундаментальной науки, но и имеет непосредственное прикладное значение: данный вид костных тканей широко применяется в современном косторезном искусстве. По химическому составу и структуре бивень мамонта имеет много общего с костными тканями. Так, бивень состоит из органической части - коллагена (20-30 mass \%), минеральной 
части - гидроксиапатита (ГАП) (60-70 mass \%) и воды (10 mass \%) [22]. По данным [23] неорганическая фаза бивня может быть описана как минеральная структура, упорядоченно расположенная относительно коллагеновых фибрилл. Сочетание коллагена и ГАП придает бивню уникальную комбинацию высокой жесткости, прочности и ударной вязкости: ГАП ответствен за высокую жесткость, в то время как коллаген улучшает ударную вязкость. Следует отметить, что минеральные кристаллы в бивне как мамонтов, так и современных слонов не являются чистыми кристаллами ГАП, как в обычных костях, а являются гибридами, где в малых количествах ионы магния и натрия замещают ионы кальция, изменяя структуру апатита, благодаря чему бивни обладают повышенными прочностными характеристиками. В то же время иерархическая, комплексно ориентированная микроструктура бивня мамонта делает ее высокоанизотропным материалом, с различными механическими свойствами в разных направлениях.

В апатитах распространены все основные типы точечных дефектов кристаллической решетки: вакансии (незанятые позиции в решетке), примеси и дефектные пары - вакансии и соответствующие атомы в междоузельном пространстве (дефекты Шоттки-Френкеля). Примесные элементы могут занимать регулярные позиции структуры (изоморфное замещение) или внедряться в междоузельные позиции. Кристаллы биогенных апатитов костной и зубной ткани имеют субмикроскопические размеры и нестехиометричный состав, могут иметь дефицит по кальцию, гидроксил- и фосфат-ионам; катионы $\mathrm{Ca}^{2+}$ в них часто замещаются на двухвалентные и трехвалентные катионы примесей, а гидроксил и фосфат ионы - на $\mathrm{CO}_{3}^{2-}\left(\mathrm{CO}_{3}^{2-} \rightarrow \mathrm{OH}^{-}, \mathrm{PO}_{4}^{3-}-\right.$ A- и В-тип изоморфизма) [18]. Изоморфные замещения (как катионные, так и анионные) оказывают сильное влияние на внутренние колебания окружающих сложных анионов (например, $\mathrm{PO}_{4}^{3-}$ ), что выражается в изменении интенсивности и смещении полосы поглощения этого аниона $[24,25]$.

Инфракрасный спектр твердого природного минерала (образца) в первом приближении можно охарактеризовать несколькими численными параметрами - количеством полос на спектре, формой каждой из них и значениями их максимумов, ширин и площадей. Значение максимума полосы несет информацию о структурном фрагменте (его искажении, деформации и др.) и типе колебаний, с которым связана данная полоса, в то время как ширина полосы в первом приближении определяется степенью упорядочения ближайшего окружения фрагмента. Таким образом, анализируя сдвиги максимумов полос, их относительные интенсивности (площади) и значения ширин, можно охарактеризовать некоторые физико-химические характеристики материала - содержание и свойства его различных структурных фрагментов [18].

Однако полосы поглощения, обусловленные различными структурными фрагментами, могут частично на- кладываться друг на друга на спектре, что затрудняет количественный анализ экспериментальных данных. Известно, что апатиты природного происхождения, а также их синтетические аналоги термоинертны: их нагревание до $1200^{\circ} \mathrm{C}$ не сопровождается какими-либо эффектами. Напротив, биогенные апатиты, содержащие в значительном количестве воду, карбонат-ионы и органическое вещество, при нагревании характеризуются целым рядом термоэффектов - потерями массы и выделением (поглощением) тепла [17]. Например, при температуре $800^{\circ} \mathrm{C}$ происходит потеря костью адсорбированной воды, преобразования неорганической части (ГАП), связанные с потерей летучих компонентов; при некоторых типах фоссилизации термическому разложению подвергаются и экзогенные вещества, поступившие в кость в процессе фоссилизации, в частности, кальцит разрушается при температуре около $700^{\circ} \mathrm{C}$, теряя при этом около $40 \%$ массы в виде $\mathrm{CO}_{2}$. Таким образом, термообработка костных тканей и изучение изменений, протекающих в них при прокаливании, с использованием метода ИК спектроскопии позволит более точно интерпретировать состав и оценить вклад внешних факторов в состав исследуемого костного объекта, в нашем случае бивня мамонта.

Целью данной работы являлось исследование состава и структуры бивня мамонта, в том числе после термообработки, методом ИК спектроскопии.

\section{Материалы и методы исследования}

Объектом исследования являлся фрагмент бивня мамонта III-IV сорта, добытый на лицензионном участке ИП „Власов“ „Илин-Сыалах“ Усть-Янского района Республики Саха (Якутия). Образцы в виде порошка были получены из бездефектной, срединной части бивня характерного молочно-белого цвета. Для гомогенизации исследуемого порошка использовали планетарную мельницу „Pulverisette-5“ (Fritsch, Германия). Измельчение производили при скорости вращения барабанов $400 \mathrm{rot} / \mathrm{min}$ в течение 5 минут. Для удаления неизмельченных фрагментов образец просеивали через сито с ячейками $0.25 \mathrm{~mm}$. Прокаливание исследуемых образцов производилось в муфельной печке „SNOL 40/1180“ (Литва) в течение 2 часов при температурах $200^{\circ} \mathrm{C}$, $400^{\circ} \mathrm{C}, 600^{\circ} \mathrm{C}, 900^{\circ} \mathrm{C}$.

Спектроскопическое исследование было выполнено на ИК спектрометре „Nicolet Protégé 460“ (США). Снятие спектров производилось по стандартной методике на образцах, таблетированных совместно с $\mathrm{KBr}$. Инфракрасные исследования выполнены в области 400-4000 $\mathrm{cm}^{-1}$.

\section{Результаты и обсуждение}

На рис. 1 представлено изменение массы образцов до и после прокаливания в муфельной печке при различных температурах. Видно, что термообработка образца ведет 


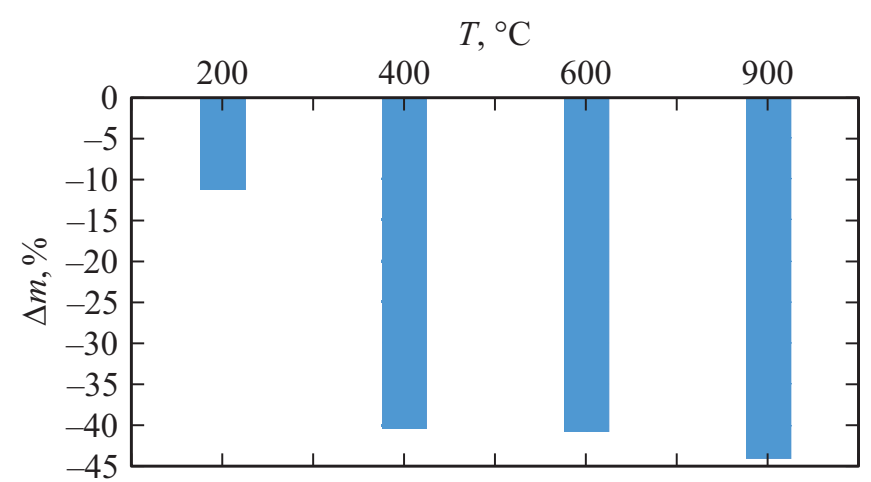

Pис. 1. Потеря массы образцов после термической обработки.

к уменьшению его массы, причем наиболее существенный скачок наблюдается в диапазоне от 200 до $400^{\circ} \mathrm{C}$, дальнейшая потеря массы не столь существенна. Полученные результаты хорошо согласуются с литературными данными о потере массы при термообработке других костных объектов, в том числе зубов $[14,15,17,26]$. Так, потери массы и экзо- и эндоэффекты фиксируются в четырех температурных диапазонах: $25-270^{\circ} \mathrm{C}(1)$, $270-430^{\circ} \mathrm{C}(2), 430-600^{\circ} \mathrm{C}(3), 700-900^{\circ} \mathrm{C}(4)$. Эти области соответствуют преобразованию разных по своей природе составляющих тканей: 1 - потере костной или зубной тканью адсорбционной воды; 2 - испарению структурной (связанной) молекулярной воды и удалению низкомолекулярных органических веществ, представленных неколлагеновыми белками с малой молекулярной массой (альбумин и др.); 3 - преобразованию высокомолекулярных органических соединений (коллагена и др.); 4 - переходу нестехиометричного карбонатзамещенного ГАП, образующего кристаллическую часть кости (зуба), в стехиометричный за счет удаления летучих компонентов, преимущественно углекислого газа $[26]$.

Также полученные данные согласуются с результатами проведенного нами ранее термогравиметрического анализа бивня мамонта [22]. В данной статье было показано, что в диапазоне температур от 25 до $1000^{\circ} \mathrm{C}$ протекает многостадийный процесс термической деструкции бивня мамонта. Так, до $200^{\circ} \mathrm{C}$ происходит испарение адсорбированной воды; в диапазоне температур $200-600^{\circ} \mathrm{C}$ выгорает органическая часть, что сопровождается протеканием как эндотермических, так и экзотермических процессов, приводящих к наиболее интенсивному сокращению массы образца; в области от 600 до $1000^{\circ} \mathrm{C}$ отмечено появление трех небольших экзотермических пиков, появление которых обусловлено протеканием процессов, связанных с преобразованием структуры минеральной части бивня мамонта - ГАП.

На рис. 2 представлен внешний вид образцов до и после термической обработки при различной температуре. Исходный образец имеет бело-серый цвет. После термообработки при $200^{\circ} \mathrm{C}$ (рис. 2,b) образец окрашивается в песочный цвет, что, вероятно, связано с испарением адсорбированной воды, а также с процессом денатурации коллагена, протекающим в диапазоне температур $25-125^{\circ} \mathrm{C}$ и обусловленном разрушением межмолекулярных перекрестных связей коллагена. При этом протеин переходит из высокоорганизованного кристаллического состояния в неупорядоченное гелеобразное желатин [27]. Кроме того, в работе [20] было показано, что окраска самого коллагена варьирует в широком диапазоне оттенков от желтовато-оранжевой до буровато-черной, что следует учитывать при определении причин изменения окраски исследуемого материала при нагревании до $200^{\circ} \mathrm{C}$. Видно (рис. 2, c), что после отжига при $400^{\circ} \mathrm{C}$ цвет образца становится темно-коричневым, отдает рыжиной, а при $600^{\circ} \mathrm{C}$ (рис. 2,d) приобретает графитовый цвет, схожий с цветом золы. Наблюдаемое изменение окраски образца можно объяснить тем, что в данном диапазоне температур происходит обугливание и выгорание органической части костных тканей - коллагена [4,22,27]. Протекание данных процессов взаимосвязано с попутным образованием сажи и других окрашенных продуктов деструкции коллагена. При $900^{\circ} \mathrm{C}$ образец приобретает белую окраску, что обусловлено полным удалением органической составляющей костных тканей, цвет образца определяется цветом минеральной составляющей костей - ГАП. Однако для более точного объяснения необходимо проведение дополнительных исследований. Например, термический анализ костных остатков проводят синхронно с масс-спектроскопическим или ИК спектроскопическим анализом выделившихся при термообработке газов. Выход газов (обычно это пары воды, углекислый газ, диоксид серы, оксид и диоксид азота, молекулярный азот и кислород, а также низкомолекулярные органические соединения с массой, не превышающей $100 \mathrm{u}$ ) происходит синхронно с эндои экзотермическими пиками на кривой дифференциального термического анализа (ДТА), что позволяет сопоставить продукты реакции с происходящими термиче-

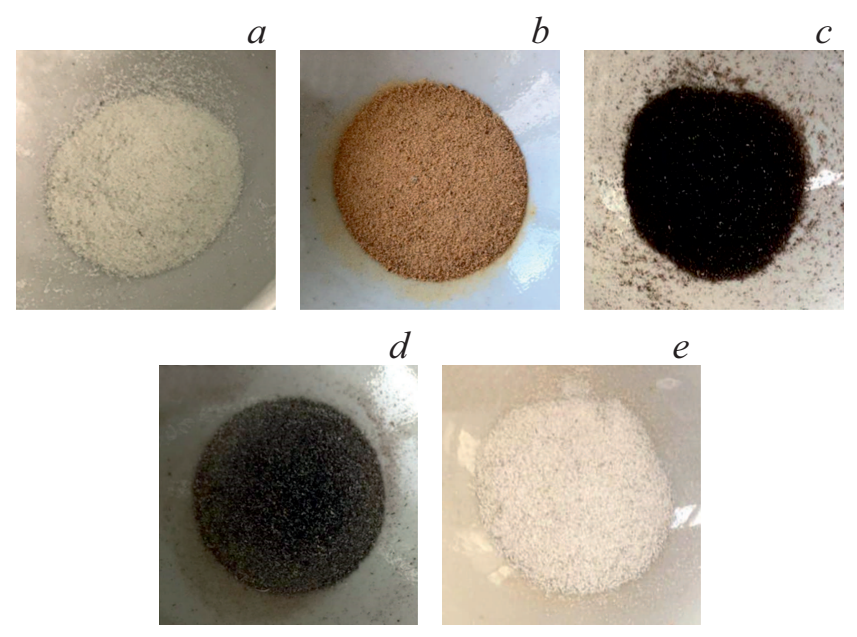

Рис. 2. Внешний вид исходного образца $(a)$ и образцов после лабораторного отжига при температурах: $200(b), 400(c)$, $600(d), 900^{\circ} \mathrm{C}(e)$. 


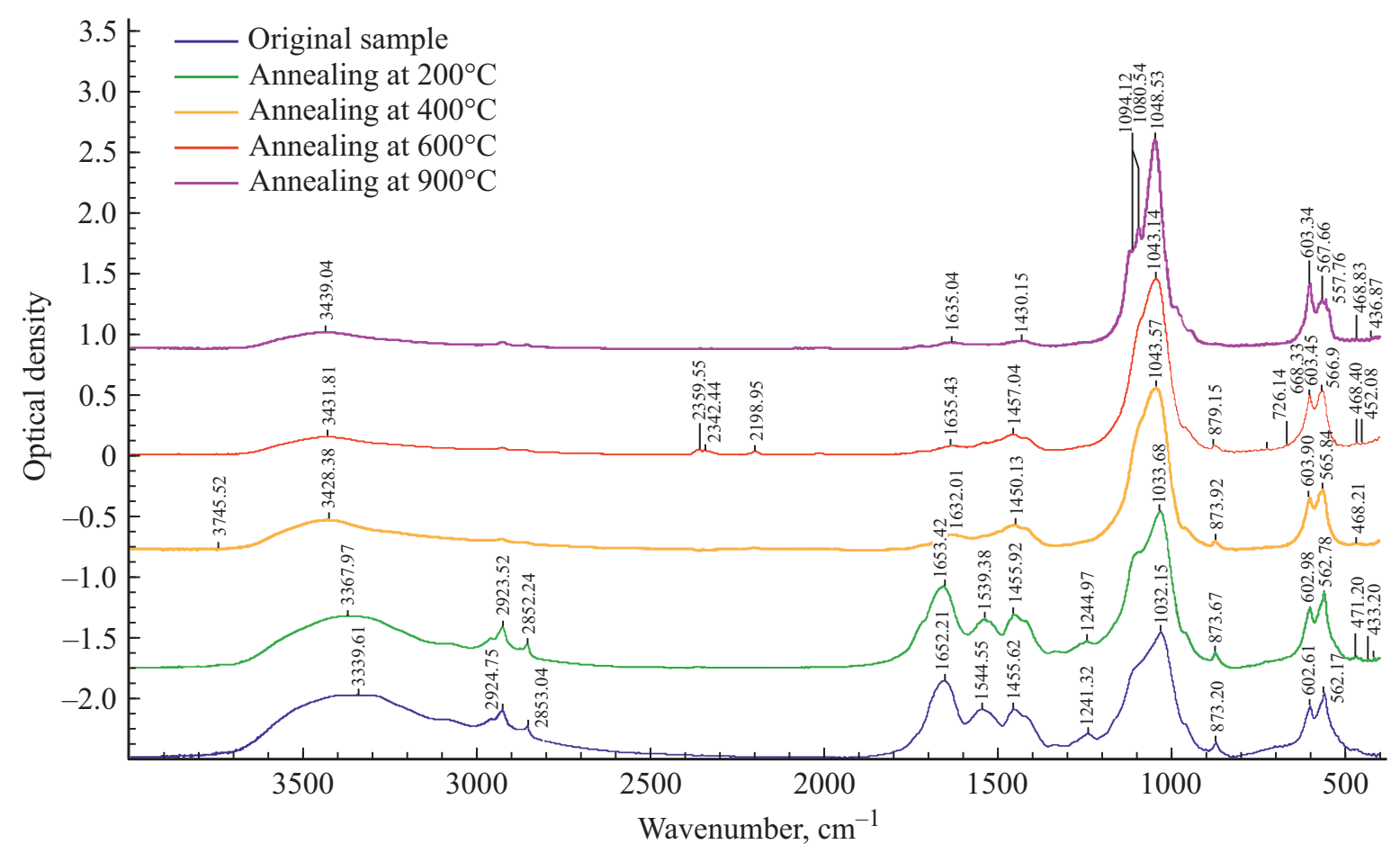

Рис. 3. Инфракрасные спектры образцов до и после лабораторного отжига при 200, 400, 600 и $900^{\circ} \mathrm{C}$.

скими процессами и предложить их описание (формулы реакций) [28]. Так, в работе [17] проведен термический анализ зубной кости методом дифференциальной сканирующей калориметрии совместно с масс-спектрометрическим анализом выходящих газов. Установлено, что выделение газообразной воды $\left(\mathrm{H}_{2} \mathrm{O}\right)$, оксидов углерода $\left(\mathrm{CO}_{2}\right)$ и азота $(\mathrm{NO})$ происходит синхронно с выгоранием органической матрицы $\left(230-600^{\circ} \mathrm{C}\right)$.

На рис. 3 приведены типичные ИК спектры образцов из бивня мамонта в исходном состоянии и подвергнутых лабораторному отжигу при различных температурах $\left(200,400,600,900^{\circ} \mathrm{C}\right)$. Расшифровку ИК спектров проводили, ссылаясь на результаты подобных исследований [8-20,29].

В таблице представлена расшифровка значений характеристических частот, полученных нами при проведении экспериментальных работ по ИК спектроскопическому исследованию бивня мамонта до и после термообработки, а также данные, полученные при ИК спектроскопическом исследовании других костных объектов, описанных в $[18,29]$. Как было упомянуто ранее, бивень мамонта состоит из коллагена, ГАП и воды. Фиксируемые на всех спектрах полосы связаны с разными физическими типами колебаний этих компонентов бивня. Колебаниям, характерным для органической фазы (коллагена), соответствуют колебания амидных группировок (А и B, I, II, III) и колебаний $\mathrm{C}-\mathrm{H}$-связи алифатических групп $\left(\mathrm{CH}, \mathrm{CH}_{2}\right.$ и $\left.\mathrm{CH}_{3}\right)$. Пикам, характерным для ГАП, соответствуют колебания ортофосфорных группировок $\mathrm{PO}_{4}^{3-}$, гидроксид-анионов, карбонат-ионов $\mathrm{CO}_{3}^{2-}$ (в случае карбонатзамещенного ГАП) и воды. Следует отметить, что вода в ГАП описывается двумя формами: $\mathrm{H}_{2} \mathrm{O}^{-}$- адсорбированная и $\mathrm{H}_{2} \mathrm{O}^{+}-$вода, структурно связанная с апатитом [17]. Также вода в молекулярном виде находится в капиллярах (дентиновых трубочках) самого бивня [30].

Коллаген представляет собой белок, состоящий из различных аминокислот - глицина, пролина, аланина, аргинина и лизина, также в небольшом количестве содержатся другие аминокислоты. В связи с этим на ИК спектре коллагена проявляются характеристические полосы поглощения различных видов амидных группировок. Колебаниям амида I соответствует полоса при $1652 \mathrm{~cm}^{-1}$, амида II $-1544 \mathrm{~cm}^{-1}$, амида III $1241 \mathrm{~cm}^{-1}$. Колебания амидов А и В частично перекрываются с полосами поглощения гидроксид-аниона и на спектре представлены полосой при $3747 \mathrm{~cm}^{-1}$. Алифатическая часть представлена валентными колебаниями $\mathrm{C}-\mathrm{H}$ в группах $\mathrm{CH}_{2}$ и $\mathrm{CH}_{3}$ при 2853 и $2924 \mathrm{~cm}^{-1}$. После термообработки при $200^{\circ} \mathrm{C}$ все компоненты коллагена сохраняются на ИК спектре. Термообработка при более высоких температурах приводит к постепенному снижению интенсивности всех полос коллагена и полному их исчезновению к $600^{\circ} \mathrm{C}$.

Гидроксиапатит на ИК спектре представлен колебаниями фосфатной группировки $\left(\mathrm{PO}_{4}^{3-}\right)$ : наиболее интенсивная полоса получена для антисимметричного валентного колебания $\mathrm{P}-\mathrm{O}$ при $1032 \mathrm{~cm}^{-1}$, для дважды вырожденных колебаний $\mathrm{O}-\mathrm{P}-\mathrm{O}$ выявлена полоса при $470 \mathrm{~cm}^{-1}$ и для трижды вырожденных колебаний - при 562 и $602 \mathrm{~cm}^{-1}$. Как уже отмечалось, ГАП в костных тканях может находиться в карбонатзамещенном виде, 
Характеристические частоты структурных фрагментов и типов колебаний бивня мамонта до и после термообработки и других костных объектов

\begin{tabular}{|c|c|c|c|c|c|c|c|}
\hline \multicolumn{7}{|c|}{ Характеристические полосы, $\mathrm{cm}^{-1}$} & \multirow{3}{*}{$\begin{array}{c}\text { Структурный фрагмент } \\
\text { и тип колебаний }\end{array}$} \\
\hline \multicolumn{5}{|c|}{ Экспериментальные данные } & \multicolumn{2}{|c|}{ Литературные данные } & \\
\hline исходный & $200^{\circ} \mathrm{C}$ & $400^{\circ} \mathrm{C}$ & $600^{\circ} \mathrm{C}$ & $900^{\circ} \mathrm{C}$ & {$[29]$} & $\overline{[18]}$ & \\
\hline \multicolumn{8}{|c|}{ Органическая составляющая } \\
\hline 1241 & 1244 & & & & & & Амид III $(\mathrm{N}-\mathrm{H})$ \\
\hline 1544 & 1539 & & & & 1547 & 1551 & Амид II $(\mathrm{N}-\mathrm{H})$ \\
\hline 1652 & 1653 & & & & & 1655 & Амид $\mathrm{I}(\mathrm{C}=\mathrm{O})$ \\
\hline $\begin{array}{l}2853 \\
2924\end{array}$ & $\begin{array}{l}2852 \\
2923\end{array}$ & & & & & $\begin{array}{l}2845 \\
2935\end{array}$ & $\begin{array}{l}\text { Валентные колебания } \mathrm{C}-\mathrm{H} \\
\text { группы } \mathrm{CH}_{2}\end{array}$ \\
\hline 2924 & 2923 & & & & & 2956 & Валентные колебания $\mathrm{C}-\mathrm{H}$ группы $\mathrm{CH}_{3}$ \\
\hline 3747 & 3852 & 3676 & & & $\begin{array}{l}3540 \\
3570\end{array}$ & & $\begin{array}{l}\text { Амид А }(\mathrm{N}-\mathrm{H}) \\
\text { Амид В }(\mathrm{C}-\mathrm{H})\end{array}$ \\
\hline \multicolumn{8}{|c|}{ Минеральная составляющая } \\
\hline 470 & 471 & 468 & 468 & 468 & 471 & & $\begin{array}{l}\text { Дважды вырожденное деформационное } \\
\text { колебание } v_{2} \mathrm{O}-\mathrm{P}-\mathrm{O} \text { в } \mathrm{PO}_{4}^{3-}\end{array}$ \\
\hline 562 & 562 & 565 & 566 & 567 & 564 & & \multirow{2}{*}{$\begin{array}{l}\text { Трижды вырожденное деформационное } \\
\text { колебание } v_{4} \mathrm{O}-\mathrm{P}-\mathrm{O} \text { в } \mathrm{PO}_{4}^{3-}\end{array}$} \\
\hline 602 & 602 & 603 & 603 & 603 & 604 & 604 & \\
\hline & & & 668 & & 670 & & Либрационные полосы поглощения $\mathrm{OH}^{-}$ \\
\hline \multirow[t]{2}{*}{873} & 873 & 873 & & & 872 & & $\begin{array}{l}\text { Деформационное колебание } \mathrm{O}-\mathrm{C}-\mathrm{O} \text { в } \\
\mathrm{CO}_{3}^{2-} \rightarrow \mathrm{PO}_{4}^{3-} \text { (В-тип) }\end{array}$ \\
\hline & & & 879 & & 879 & & $\begin{array}{l}\text { Деформационное колебание } \mathrm{O}-\mathrm{C}-\mathrm{O} \text { в } \\
\mathrm{CO}_{3}^{2-} \rightarrow \mathrm{OH}^{-} \text {(А-тип) }\end{array}$ \\
\hline 1032 & 1033 & 1043 & 1043 & 1048 & 1081 & 1050 & \multirow{2}{*}{$\begin{array}{l}\text { Антисимметричное валентное } \\
\text { колебание } \mathrm{P}-\mathrm{O} \text { в } \mathrm{PO}_{4}^{3-} v_{3}\end{array}$} \\
\hline & & & & 1094 & & & \\
\hline & & & & 1120 & & 1100 & $\begin{array}{l}\text { Симметричное валентное колебание } \mathrm{P}-\mathrm{O} \text { в } \\
\mathrm{PO}_{4}^{3-} v_{1}\end{array}$ \\
\hline 1455 & 1455 & 1450 & 1457 & 1430 & $\begin{array}{l}1452 \\
1498 \\
1547 \\
\end{array}$ & $\begin{array}{l}1412 \\
1455\end{array}$ & $\begin{array}{l}\text { Антисимметричное валентное } \\
\text { колебание } \mathrm{C}-\mathrm{O} \text { в } \\
\mathrm{CO}_{3}^{2-} \rightarrow \mathrm{OH}^{-}(\mathrm{A}-\mathrm{-} и п) \\
\end{array}$ \\
\hline 1652 & 1653 & 1632 & 1635 & 1635 & 1640 & 1640 & $\begin{array}{l}\text { Деформационное } \\
\text { колебание } \mathrm{H}-\mathrm{O}-\mathrm{H} \text { в } \mathrm{H}_{2} \mathrm{O}\end{array}$ \\
\hline 3339 & 3367 & 3428 & 3431 & 3439 & 3400 & 3400 & Валентные колебания $\mathrm{OH}^{-}$ \\
\hline 3747 & 3852 & 3676 & & & $\begin{array}{l}3540 \\
3570\end{array}$ & & $\begin{array}{l}\text { Валентные } \\
\text { колебания ОН }\end{array}$ \\
\hline \multicolumn{8}{|c|}{ Вода } \\
\hline & & & 668 & & 670 & & Либрационные полосы поглощения $\mathrm{OH}^{-}$ \\
\hline 1652 & 1653 & 1632 & 1635 & 1635 & 1640 & 1640 & $\begin{array}{l}\text { Деформационное } \\
\text { колебание } \mathrm{H}-\mathrm{O}-\mathrm{H} \text { в } \mathrm{H}_{2} \mathrm{O}\end{array}$ \\
\hline 3339 & 3367 & 3428 & 3431 & 3439 & 3400 & 3400 & Валентные колебания $\mathrm{OH}^{-}$ \\
\hline 3747 & 3852 & 3676 & & & $\begin{array}{l}3540 \\
3570\end{array}$ & & $\begin{array}{l}\text { Валентные } \\
\text { колебания OH }\end{array}$ \\
\hline
\end{tabular}


причем карбонат-анионы в ГАП могут замещать как фосфат-анионы, так и гидроксид-анионы. На спектре исследуемого образца выявлены полосы, показывающие, что в нашем случае присутствуют оба типа замещения. А-тип замещения выражен антисимметричным валентным колебанием $\mathrm{C}-\mathrm{O}\left(\mathrm{CO}_{3}^{2-} \rightarrow \mathrm{OH}^{-}\right.$) (полосой при $1455 \mathrm{~cm}^{-1}$ ) и деформационными колебаниями О-C-O (полосой при $879 \mathrm{~cm}^{-1}$ ), при этом данный вид колебаний выявлен только для образца, термообработанного при $600^{\circ} \mathrm{C}$. В-тип замещения $\left(\mathrm{CO}_{3}^{2-} \rightarrow \mathrm{PO}_{4}^{3-}\right)$ представлен деформационными колебаниями $\mathrm{O}-\mathrm{C}-\mathrm{O}$ при $873 \mathrm{~cm}^{-1}$, антисимметричные валентные колебания $\mathrm{C}-\mathrm{O}$ выявлены не отчетливо, что, вероятно, связано с наложением антисимметричных колебаний А- и В-типов замещений. Гидроксид-анионы на спектре проявляются в виде либрационных колебаний при $668 \mathrm{~cm}^{-1}$ (выявлено только при $\left.600^{\circ} \mathrm{C}\right)$, деформационных колебаний при $1652 \mathrm{~cm}^{-1}$ и валентных колебаний при 3339 и $3747 \mathrm{~cm}^{-1}$. Следует отметить, что полосы при 1652 и $3747 \mathrm{~cm}^{-1}$, вероятно, налагаются на полосы поглощения амидов I и А и В соответственно.

При термообработке интенсивность полос, характерных для карбонат- и гидроксид-анионов, постепенно снижается и при $900^{\circ} \mathrm{C}$ данные полосы практически полностью исчезают, распознаются лишь следовые количества данных анионов. Полосы, характерные для фосфат-анионов, сохраняют свою интенсивность, однако к $900^{\circ} \mathrm{C}$ наблюдается их вырождение, сопровождающееся сначала образованием выраженного плеча, а затем полным расщеплением пиков. Такое изменение формы данных пиков может свидетельствовать о преобразовании структуры минеральной составляющей бивня, заключающемся в преобразовании нестехиометричного ГАП, образующего кристаллическую часть кости, в стехиометричный за счет удаления карбонат- и гидроксид-анионов.

Третий компонент бивня мамонта - вода - проявляется на спектре широкой диффузной полосой при $3339 \mathrm{~cm}^{-1}$, данная полоса представляет собой наложение нескольких характеристических полос, включая колебания гидроксид-аниона, амидов А и В. Также вода представлена деформационным колебанием $\mathrm{H}-\mathrm{O}-\mathrm{H}$ при $1652 \mathrm{~cm}^{-1}$, причем данный пик налагается на пик колебания амида I. При термообработке с повышением температуры интенсивность данных пиков снижается и практически полностью исчезает к $900^{\circ} \mathrm{C}$.

\section{Выводы}

Таким образом, ИК спектроскопическое исследование образцов из бивня мамонта позволило выявить весь комплекс функциональных группировок, характерных для различных составляющих изучаемого объекта. Исследование структуры образцов до и после термообработки позволило выявить изоморфные замещения в структуре костного ГАП: карбонат-анионы замещают гидроксид(А-тип замещения) и фосфат-анионы (В-тип замещения).
Установлено, что после термообработки при $600^{\circ} \mathrm{C}$ органическая составляющая бивня полностью выгорает, а к $900^{\circ} \mathrm{C}$ минеральная составляющая из нестехиометричного ГАП переходит в стехиометричный за счет удаления ряда летучих компонентов минеральной части (преимущественно углекислого газа) и полного удаления воды и органической составляющей. В перспективе ИК спектроскопия как экспресс-метод анализа может быть использована для определения структурных неоднородностей ГАП в бивнях мамонта, обнаруженных в разных вмещающих средах и имеющих разные характеристики сохранности и внешнего вида, что позволит определить некоторые особенности жизнедеятельности, гибели и захоронения животных, а также может иметь значение при использовании бивня мамонта как сырья для косторезного промысла.

\section{Финансирование работы}

Статья подготовлена в рамках государственного задания № АAАА-А20-120011490003-9.

\section{Конфликт интересов}

Авторы заявляют, что у них нет конфликта интересов.

\section{Список литературы}

[1] K. Janssens, L. Vincze, B. Vekemans, C.T. Williams, M. Radtke, M. Haller, A. Knochel. Fresenius J. Anal. Chem., 363 (4), 413 (1999). DOI: 10.1007/s002160051212

[2] K. M. Lee, J. Appleton, M. Cooke, K. Sawiska-Kapusta, M. Damer. Fresenius J. Anal. Chem., 364 (3), 245 (1999). DOI: $10.1007 / \mathrm{s} 002160051331$

[3] Y. Fernandez-Jalvo, M.D.M. Monfort. Geobios, 41 (1), 157 (2008). DOI: 10.1016/j.geobios.2006.06.006.

[4] I. Revenko, F. Sommer, D.T. Minh, R. Garrone, J. Franc. Biol. Cell, 80 (1), 67(1994). DOI: 10.1016/0248-4900(94)90019-1

[5] В.И. Николаев, М. Барбиери, С. Даванзо, Т.В. Кузнецова, А. Лонжинелли, Л.Д. Сулержицкий, П. Якумин. В сб.: Квартер-2005: Материалы IV Всерос. совещания по изучению четвертичного периода. Под ред. Н.П. Юшкина („Геопринт“, Сыктывкар, 2005), С. 297-299.

[6] М.Л. Зорина, А.Б. Кольцов, О.В. Франк-Каменецкая, О.В. Озаровская. Историческая геология и эволюционная география, 4, 51 (2004).

[7] О.В. Озаровская, М.Л. Зорина. Записки российского минералогического общества, 137 (5), 73 (2008).

[8] L. Wang, H. Fan, J. Liu, H. Dan, Q. Ye, M. Deng. Mineralogical Magazine, 71 (5), 509 (2007). DOI: 10.1180/minmag.2007.071.5.509

[9] H. Edwards, S. Jorge-Villar, F. Nik, A. Nlin, S. O'Connor, D. Charlton. Analytical and Bioanalytical Chemistry, 383 (4), 713 (2005). DOI: 10.1007/s00216-005-0011-z

[10] L.E. Cartier, M.S. Krzemnicki, M. Gysi, B. Lendvay, N.V. Morf. J. Gemmology, 37 (3), 282 (2020). DOI: $10 / 15506 / J o G .2020 .37 .3 .282$

[11] M. Ch. Chang, J. Tanaka. Biomaterials, 23 (24), 4811 (2002). DOI: $10.1016 / \mathrm{S} 0142-9612(02) 00232-6$ 
[12] C. Chappard, G. Andre, M. Daudon, D. Barin. Comptes Rendus Chimie. 19 (11), 1625 (2016). DOI: $10.1016 /$ j.crci.2015.03.015

[13] A. Grunenwald, C. Keyser, A.M. Sautereau, E. Crubery, B. Ludes, C. Drouet. J. Archaeological Science, 49, 134 (2014). DOI: 10.1016/j.jas.2014.05.004

[14] K. Haberko, M. Bucko, J. Brzezinska-Miecznik, M. Haberko, W. Mozgawa, T. Panz, A. Pyda, J. Zarebski. J. European Ceramic Society, 26 (4), 537 (2006).

DOI: 10.1016/j.jeurceramsoc.2005.07.033

[15] T. Sakae, H. Oinuma, M. Higa, Y. Kozawa. J. Oral Biosciences, 47 (1), 83 (2005). DOI: 10.1016/S1349-0079(05)80013-1

[16] В.М. Золотарев, Г.А. Хлопачев. Опт. и спектр., 114 (6), 1036 (2013). DOI: 10.7868/S0030403413040235

[17] С.Л. Вотяков, Д.В. Киселёва, Ю.В. Щапова, Н.Г. Смирнов, Н.О. Садыкова. Физико-химические характеристики ископаемых костных остатков млекопитающих и проблема оценки их относительного возраста. Ч. 1. Термический и масс-спектрометрический элементный анализ. (Издательство „Гошицкий“, Екатеринбург, 2009).

[18] С.Л. Вотяков, Д.В. Киселёва, Ю.В. Щапова, Н.Г. Смирнов, Н.О. Садыкова. Физико-химические характеристи$\kappa и$ ископаемых костных остатков млекопитающих $u$ проблема оценки их относительного возраста. Ч. 2. ИК и радиоспектроскопия, микроскопия (Издательство „Гошицкий“, Екатеринбург, 2009).

[19] В.М. Золотарев. ОПт. и спектр., 116 (4), 645 (2014). DOI: $10.7868 / \mathrm{S} 0030403414040308$

[20] В.И. Силаев, Д.В. Пономарев, Ю.С. Симакова, С.Н. Шанина, И.В. Смолева, Е.М. Тропников, А.Ф. Хазов. Вестник Института геологии Коми НЦ УрО РАН, $257(5), 19$ (2016). DOI: 10.19110/2221-1381-2016-5-19-31

[21] M.J. Glimcher. Rev. Miner. Geochem, 64(1), 223 (2006). DOI: $10.2138 / \mathrm{rmg} .2006 .64 .8$

[22] T.M. Solovev, E.S. Petukhova, G.V. Botvin, T.A. Isakova, V.V. Pavlova. IOP Conf. Ser: Mater. Sci. Eng. 1079 (4), 042011 (2021). DOI: 10.1088/1757-899X/1079/4/042011

[23] С.Н. Данильченко. Вісник СумДу. Серія Фізика, математика, механіка, 2, 33 (2007).

[24] Р.Г. Кнубовец, Л.Д. Кисловский. В сб.: Физика апатита, под ред. В.С. Соболева („Наука“ Сибирское отделение, Новосибирск, 1975).

[25] А.Б. Брик, О.В. Франк-Каменецкая, В.А. Дубок, Е.А. Калиниченко, М.А. Кузьмина, М.Л. Зорина, Н.А. Дудченко, А.М. Калиниченко, Н.Н. Багмут. Минералогический журнал. 35 (3), 3 (2013).

[26] Л.Г. Гилинская, Т.Н. Григорьева, Ю.Н. Занин и др. Геохимия, 39 (3), 279 (2001).

[27] T.M. De Batista, V.C.A. Martins, A.M. De Guzzi Plepis. J. Thermal Analysis and Calorimetry, 95, 945 (2009). DOI: 10.1007/s10973-007-8897-7

[28] A. Onishi, P.S. Thomas, B.H. Stuart et al. J. Thermal Analysis and Calorimetry, 88 (2), 405 (2007). DOI: $10.1007 / \mathrm{s} 10973-006-8135-8$

[29] J. Shi, A. Klocke, M. Zhang, U. Bismayer. Eur. J. Mineral., 17 (5), 769 (2005). DOI: 10.1127/0935-1221/2005/0017-0769

[30] Г.А. Хлопачев, Е.Ю. Гиря. Секреты древних косторезов Восточной Европы и Сибири: приемы обработки бивня мамонта и рога северного оленя в каменном веке (по археологическим и экспериментальным данным), („Наука“, СПб. 2010). 